\title{
Shared transcriptional correlations in seed formation and in plants response to drought Maital Ashkenazi* and Menachem Moshelion
}

\author{
Address: The Robert H. Smith Institute of Plant Sciences and Genetics in Agriculture, The Hebrew University of Jerusalem, Rehovot, 76100, Israel \\ Email: Maital Ashkenazi* - ashkenaz@agri.huji.ac.il \\ * Corresponding author
}

from Third International Society for Computational Biology (ISCB) Student Council Symposium at the Fifteenth Annual International Conference on Intelligent Systems for Molecular Biology (ISMB)

Vienna, Austria. 2I July 2007

Published: 20 November 2007

BMC Bioinformatics 2007, 8(Suppl 8):P5 doi:I0.1 |86/I47|-2 I05-8-S8-P5

This abstract is available from: http://www.biomedcentral.com//47I-2105/8/S8/P5

(C) 2007 Ashkenazi and Moshelion; licensee BioMed Central Ltd.

\section{Background}

Plant seed formation involves considerable water loss, while, at the same time, the dehydrated tissues exhibit desiccation tolerance preserving their vitality. Some of the genes expressed at these specific life stages are known to be involved in response to externally imposed water stress (e.g. osmotic stress and salt stress). Since functionally related genes are often co-expressed, revealing shared transcriptional correlations in response to the above dehydration processes in Arabidopsis thaliana plants may offer new tools for manipulating desiccation tolerance in plants.

\section{Materials and methods}

Dehydration-related DNA microarray datasets from AtGenExpress [1,2] were normalized (MAS 5.0) and log2 transformed. One thousand genes from each dataset with detectable and variable expression across conditions were selected for further analysis as follows: Pearson Correlation Coefficients (PCCs) were calculated for each pair of genes. Networks of transcriptional correlations were created from gene pairs with PCCs bigger than 0.8 or smaller than -0.8 (positive and negative transcriptional correlations, respectively). After removing transcriptional correlations related to common factors other than dehydration (i.e. circadian rhythm, temperature etc.) we intersected the networks of osmotic stress, salt stress and stages 8-10 of seed formation using Cytoscape [3].

\section{Results}

We identified new transcriptional correlations shared by plant responses to dehydration and by the acquisition of desiccation tolerance in the final stages of seed formation (Fig. 1). We found striking enrichment (ten times more than on the ATH1 array) with genes related to plants response to dehydration, such as genes of molecular chaperons. Transcripts of their homologues are also abundant in the resurrection plant Selaginella lepidophylla during dehydration [4]. About $20 \%$ of the genes are of unknown biological function. Based on our results, we propose these genes play a role in plant response to dehydration. Similar results were obtained with networks of shoots exposed to dehydration stresses.

\section{Conclusion}

Computational approach allowed us to detect transcriptional correlations and to suggest a role in plant response to dehydration for genes with unknown function. Understanding transcriptional regulation during dehydration is an important first step in deciphering - and for future manipulation - of plant drought tolerance. 

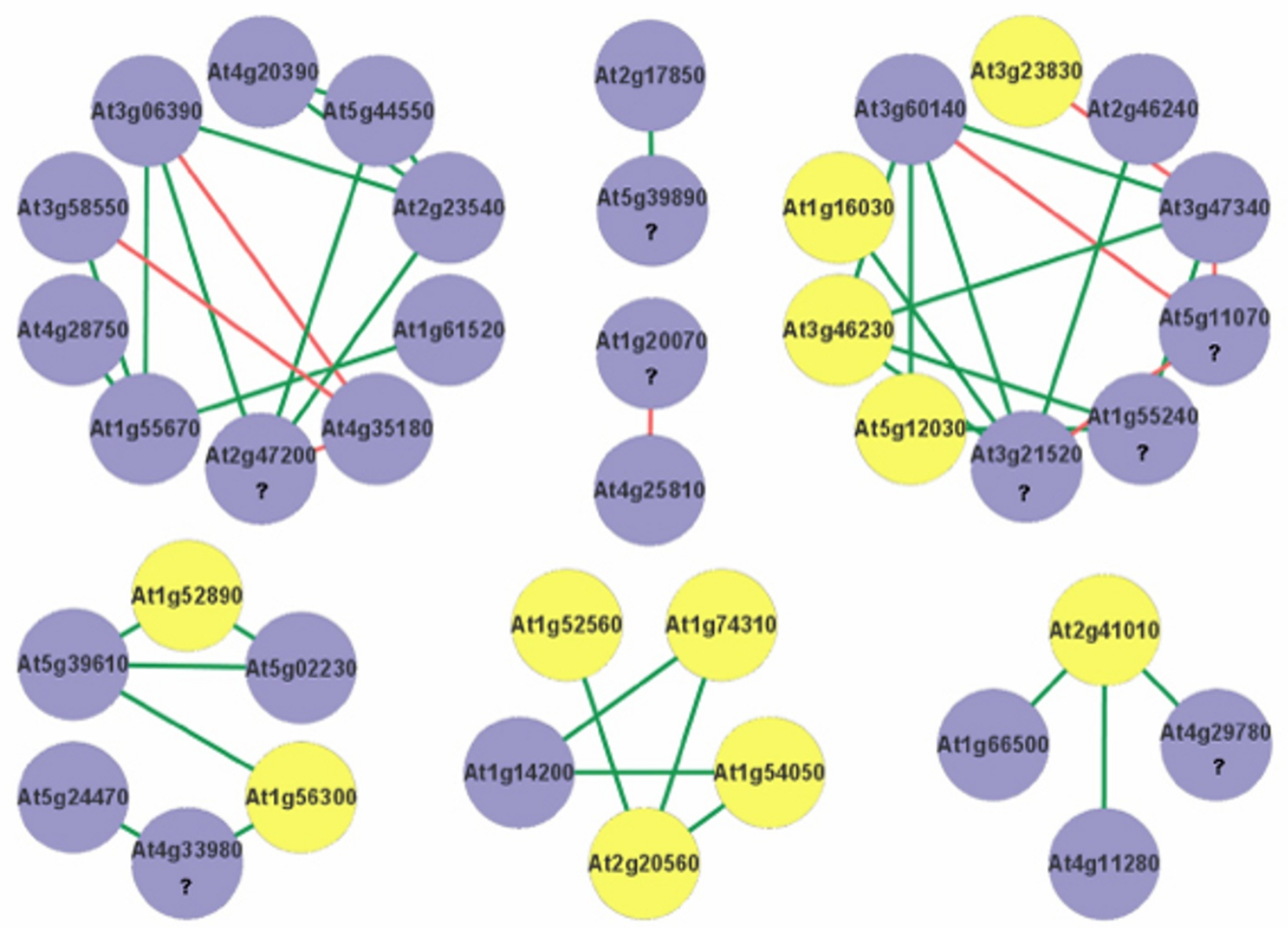

\section{Figure I}

Shared transcriptional correlations in drought-stressed roots and in seed formation. Yellow: genes annotated as being involved in plant response to dehydration. Question marks - genes of unknown function. Green and red edges represent positive and negative transcriptional correlations, respectively.

\section{Acknowledgements}

We thank Dr. Nava Moran for useful comments.

\section{References}

I. Schmid M, Davison TS, Henz SR, Pape UJ, Demar M, Vingron M, Scholkopf B, Weigel D, Lohmann JU: A gene expression map of Arabidopsis thaliana development. Nature Genetics 2005, 37(5):50I-506.

2. Kilian J, Whitehead D, Horak J, Wanke D, Weinl S, Batistic O, D'Angelo C, Bornberg-Bauer E, Kudla J, Harter K: The AtGenExpress global stress expression data set: protocols, evaluation and model data analysis of UV-B light, drought and cold stress responses. Plant Journal 2007, 50:347-363.

3. Shannon P, Markiel A, Ozier O, Baliga NS, Wang JT, Ramage D, Amin $\mathrm{N}$, Schwikowski B, Ideker T: Cytoscape: A software environment for integrated models of biomolecular interaction networks. Genome Research 2003, I3(I I):2498-2504.

4. Iturriaga G, Cushman MAF, Cushman JC: An EST catalogue from the resurrection plant Selaginella lepidophylla reveals abiotic stress-adaptive genes. Plant Science 2006, 170: I I73-I I84.

\begin{tabular}{|l|}
\hline Publish with BioMed Central and every \\
scientist can read your work free of charge \\
"BioMed Central will be the most significant development for \\
disseminating the results of biomedical research in our lifetime. " \\
Sir Paul Nurse, Cancer Research UK \\
Your research papers will be: \\
• available free of charge to the entire biomedical community \\
• peer reviewed and published immediately upon acceptance \\
• cited in PubMed and archived on PubMed Central \\
• yours - you keep the copyright \\
Submit your manuscript here: \\
http://www.biomedcentral.com/info/publishing_adv.asp
\end{tabular}

